\title{
Disclosure of medical error: policies and practice
}

\author{
Jawahar Kalra PhD FRCPC K Lorne Massey MD Amith Mulla MB BS
}

J R Soc Med 2005;98:307-309

In any healthcare process, some error is inevitable. ${ }^{1}$ As indicated in the US Institute of Medicine's report To Err is Human, ${ }^{2}$ the challenge is to cut the rate of error to a minimum. In Canada, various strategies are being applied to this end and the Federal Government has established a Patient Safety Institute. The UK likewise has a National Patient Safety Agency. However, in the many countries ${ }^{3}$ where efforts are being made to reduce adverse events and errors, a neglected issue is honest disclosure to the patient or family. In this paper we examine the central issues, discuss the dilemmas concerning 'apology' and suggest how we might work towards a systematic and effective process.

\section{PREVENTABLE ADVERSE EVENTS}

The rate of adverse events in hospital patients from studies worldwide has varied from $3.7 \%$ in New York to $11 \%$ in UK hospitals and $16.6 \%$ in Australian hospitals. ${ }^{4-6}$ In Canada two recent papers give rates of $5 \%$ and $7.5 \%, 7,8$ and the report Health Care in Canada 2004 states that about 5.2 million Canadians (representing a quarter of the population) have experienced a preventable adverse event either in themselves or in a family member. ${ }^{9}$ The wide variation in reported adverse event rates is partly due to differences in study methods and patient selection. Moreover, there is no agreement on what constitutes 'preventability'. Only a few studies looked at preventability of adverse events as part of their original design. ${ }^{5-7}$ But there is now a consensus that, in terms of patient safety, many health systems perform below their potential best.

What, then, is the argument for being open with the patient and family, even when the repercussions may be unpleasant and costly? We have to remember that inappropriate blame attribution, to serve regulatory needs, will merely alienate professionals and discourage them from participating in system improvements.

The foremost justification is to safeguard public trust in the medical profession, and the responsibility to disclose medical errors is acknowledged in codes of professional ethics. ${ }^{10}$ But another argument is that patients have a right to information about errors in terms of the respect due to

Department of Pathology, College of Medicine, University of Saskatchewan and Royal University Hospital, Saskatoon, Saskatchewan, Canada

Correspondence to: Professor Jay Kalra

E-mail: jay.kalra@saskatoonhealthregion.ca them as persons, and indeed patients expect doctors to recognize this duty. ${ }^{12}$ In addition, failure to disclose an error during the course of patient care may compromise not only autonomy but also informed consent. For example, disclosure may be essential if a patient is to give consent for treatment of injury caused by an error. ${ }^{13}$ Thus, failure to disclose information on medical mistakes adversely affects the patient's ability to make an intelligent decision, impairs patient trust in the doctor and increases the likelihood of a malpractice suit. ${ }^{14}$

\section{HONEST DISCLOSURE-PROGRESS AND INITIATIVES \\ USA}

In response to the Institute of Medicine's call for greater transparency and effective patient safety standards, ${ }^{2}$ we proposed a 'no fault' model whereby disclosure of adverse events to patients is integral to accreditation. ${ }^{15}$ In 2001 the US Joint Commission on Accreditation of Healthcare Organizations (JCAHO) announced an 'unanticipated outcome' policy that demands disclosure of a critical event by the provider or the institution. ${ }^{16}$ The only ambiguity concerns the operational definition of an unanticipated outcome, which institutions must decide for themselves. In general, the Joint Commission recommends that the disclosure should be conducted by the doctor, though on occasion some other member of the team will be more suitable. Some individual States, among them Pennsylvania, Nevada and Florida, have in recent times complemented the federal initiatives by imposing a statutory duty on establishments to notify patients in case of an adverse event. ${ }^{17-19}$

\section{Australia}

In 2002, a committee of the Australian Council for Safety and Quality in Health Care offered an approach to achieving open and honest communication with patients after an adverse event, ${ }^{20}$ addressing the interests of consumers, healthcare professionals, managers and organizations. Like the policy proposed by the US Joint Commission, the draft standard is flexible in allowing development of local policies and procedures. The unique aspect of the Australian draft standard is the integration of disclosure with a risk management analysis and investigation of the critical event. The level of investigation will depend on grading of the 
event according to the extent of injury and the likelihood of its occurrence.

\section{UK}

The National Health Service in 2003 declared a 'duty of candour', whereby doctors and managers must inform a patient of an act of negligence or omission that causes harm. ${ }^{21}$ This scheme offers the patient a package in the form of remedial care, apologies and monetary compensation without the need for litigation. The affected patients, if they accept the compensation package, waive their right to litigate.

\section{Canada}

The Royal College of Physicians and Surgeons of Canada in 2002 called for healthcare systems to promote disclosure on safety issues to all partners including patients, ${ }^{22}$ but no uniform Canadian guidelines on the subject are yet in place. Reviewing nationwide practices on adverse event disclosure we found that just a few licensing bodies had ratified policies for disclosure and discussion of negative outcomes during patient care. The College of Physicians and Surgeons of Saskatchewan requires the physician to disclose any adverse events and errors to the patient or his or her representative as soon as possible during care, with ten guidelines on the steps in purposeful disclosure. ${ }^{23}$ The College of Physicians and Surgeons of Manitoba requires the physician to avoid all speculations and state plain facts as known at the time. ${ }^{24}$ In 2003, after lengthy deliberation, the College of Physicians and Surgeons of Ontario approved a policy that made disclosure of harm to patients a standard of practice, ${ }^{25}$ even in circumstances when such disclosure may result in a complaint or a malpractice insurance claim. A special aspect of the Ontario College policy is the guideline for medical trainees (i.e. students or residents), who are advised to report an adverse event either to their supervisor or to the 'most responsible physician'. (The policy also specifies that the patient is free to refuse discussion of the event.) The College of Physicians and Surgeons of Quebec has no distinct policy on adverse event disclosure to patients, but synthesizes the concept of disclosure in its code of ethics. ${ }^{26}$

In Canada, there is nothing in the nature of the US Joint Commission initiative, making disclosure of adverse events a requirement for hospital accreditation. The absence of laws, federal or provincial, mandating adequate disclosure of an adverse event to the patient is a key area of concern.

\section{THE DILEMMA OF AN APOLOGY}

A key recommendation of the various global policies on medical error disclosure is to apologize to the patient, thus soothing anger and lessening suspicion. ${ }^{27}$ But doctors and others, though possibly willing to accept responsibility and express regret, may be reluctant to pursue this course if it amounts to admission of guilt or legal liability. Liebman and Hyman $^{28}$ distinguish between two types of apology'apology of sympathy' and 'apology of responsibility'. Since some legal jurisdictions consider an apology as evidence of liability, these authors suggest that the risks and benefits of an apology should be weighed up beforehand by the doctors and hospital administrators; and, indeed, it is not uncommon to find risk managers and hospital attorneys discouraging a timely apology for fear of encouraging a lawsuit. Herein lies a dilemma, in view of the perception that an appropriately worded apology by the doctor can reduce the likelihood of a lawsuit. ${ }^{29}$ This conflict is partly resolved by measures such as those introduced in Massachusetts and Florida, whereby apologies or expressions of regret to patients are legally protected. ${ }^{30,31}$ Some medical errors are due to system failures ${ }^{32}$ and in these circumstances the doctor may be disinclined to offer an 'apology of responsibility'. An insincere apology driven by regulatory standards and institutional policies may carry its own risks.

\section{CONCLUSIONS}

The culture of malpractice suits continues to grow. Suits filed solely for monetary considerations abuse the tort system and set an unacceptable trend. ${ }^{33}$ Blame and retribution may have their place, but society's interests are best served by creating a trusting environment that promotes honest disclosure of error. To restore trust successfully and perhaps lower malpractice claims, both the public and health care providers must avoid the 'shame and blame' game. The other challenge lies in achieving a balance between a non-punitive approach to error and the need for a process that includes accountability and suitable compensation for patients. We suggest that this balance can be achieved by a system-based error disclosure programme.

\section{REFERENCES}

1 Institute of Medicine. Crossing the Quality Chasm: A New Health System for the 21st Century. Washington, DC: National Academy Press, 2001

2 Kohn LT, Corrigan JM, Donaldson MS, eds. Committee on Quality of Healthcare in America, Institute of Medicine. To Err is Human: Building a Safer Health System. Washington, DC: National Academy Press, 2000

3 Federal/Provincial/Territorial Minister of Health establish new Canadian Patient Safety Institute [www.hc-sc.gc.ca/english/media/ releases/2003/2003_99.htm]. Accessed 10 October 2004

4 Brennan TA, Leape LL, Laird NM, Hebert L, et al. Incidence of adverse events and negligence in hospitalized patients. Results of the Harvard Medical Practice Study I. N Engl J Med 1991;324:370-6

5 Wilson RM, Runciman WB, Gibberd RW, Harrison BT, Newby L, Hamilton JD. The Quality in Australian Health Care Study. Med J Aust 1995;163:458-71 
6 Vincent C, Neale G, Woloshynowych M. Adverse events in British hospitals: preliminary retrospective record review. BMJ 2001;322:517-19

7 Forster AJ, Asmis TR, Clark HD, et al. Ottawa Hospital Patient Safety Study: incidence and timing of adverse events in patients admitted to a Canadian teaching hospital. Can Med Assoc J 2004;170:1235-40

8 Baker GR, Norton PG, Flintoft V, et al. The Canadian Adverse Events Study: the incidence of adverse events among hospital patients in Canada. Can Med Assoc J 2004;170:1678-86

9 Gagnon L. Medical errors affect nearly $25 \%$ of Canadians. Can Med Assoc J 2004;171:123

10 American Medical Association Council on Ethical and Judicial Affairs. Code of Medical Ethics: Current Opinions. Chicago: American Medical Association, 2000

11 Hebert PC, Levin AV, Robertson G. Bioethics for clinicians: 23. Disclosure of medical error. Can Med Assoc J 2001;164:509-13

12 Gallagher TH, Waterman AD, Ebers AG, Fraser VJ, Levinson W. Patients' and physicians' attitudes regarding the disclosure of medical errors. JAMA 2003;289:1001-7

13 Robertson GB. Fraudulent concealment and the duty to disclose medical mistakes. Alberta Law Rev 1987;25:215-23

14 Hickson GB, Clayton EW, Githens PB, Sloan FA. Factors that prompted families to file medical malpractice claims following perinatal injuries. JAMA 1992;267:1359-63

15 Kalra J, Saxena A, Mulla A, Neufeld H, Qureshi M, Massey KL. Medical Error: A Clinical Laboratory Approach in Enhancing Quality Care [Abstract]. Clin Biochemistry 2004;37:732-3

16 Joint Commission on Accreditation of Healthcare Organization. Comprehensive Accreditation Manual for Hospitals: The Official Handbook. Illinois: JCAHO, 2004

17 Medical Care Availability and Reduction of Error (Mcare) Act. $13 \mathrm{~Pa} \mathrm{C}$ S $\$ 308(2002)$

18 Nev Rev Stat $\$ 439.835$ (2003)
19 Fla Stat $\$ 395.1051(2003)$

20 Australian Council for Safety and Quality in Health Care. Draft Open Disclosure Standard. Standards Australia, XX 1234-2002, Draft v5.2

21 Dyer C. NHS Staff should inform patients of negligent acts. BMJ 2003;327:7

22 National Steering Committee on Patient Safety. Building a Safer System - a National Integrated Strategy for Improving Patient Safety in Canadian Health Care. NSCPS, 2002

23 Physician disclosure of adverse events and errors that occur in the course of patient care [www.quadrant.net/cpss/index.html]. Accessed 15 October 2004

24 Physician disclosure of harm that occurs in the course of patient care [www.umanitoba.ca/colleges/cps/Guidelines_and_Statements/169.html]. Accessed 15 October 2004

25 Borsellino M. Disclosure of harm to be standard of practice. Medical Post 2003;39(11)

26 Code of Ethics of Physicians [www.cmq.org/UploadedFiles/ cmqcodedeontoan.pdf]. Accessed 15 October 2004

27 Cohen JR. Apology and organizations: exploring an example from medical practice. Fordham Urban Law 2000;27:1447-82

28 Liebman CB, Hyman CS. A mediation skills model to manage disclosure of errors and adverse events to patients. Health Affairs 2004;23(4):22-32

29 Mazor KM, Simon SR, Yood RA, et al. Health plan members' views about disclosure of medical errors. Ann Intern Med 2004;140: 409-18

30 Mass Gen Laws ch 233, §23D

31 Fla Stat $\$ 90.4026$

32 Kalra J. Medical error: an introduction to concepts. Clin Biochem 2004;37:1043-51

33 Kalra J, Massey KL, Mulla A. Disclosure of errors. Health Affairs 2004;23:273-4 